\title{
The density of macrophages in the invasive front is inversely correlated to liver metastasis in colon cancer
}

\author{
Qiang Zhou ${ }^{1,2}$, Rui-Qing Peng ${ }^{1,2}$, Xiao-Jun Wu ${ }^{1,3}$, Qing Xia ${ }^{1,2}$, Jing-Hui Hou ${ }^{1,4}$, Ya Ding ${ }^{1,2}$, Qi-Ming Zhou ${ }^{1,2}$, \\ Xing Zhang ${ }^{1,2}$, Zhi-Zhong Pang ${ }^{1,3}$, De-Sen Wan ${ }^{1,3}$, Yi-Xin Zeng ${ }^{1,2}$, Xiao-Shi Zhang ${ }^{1,2^{*}}$
}

\begin{abstract}
Background: Although an abundance of evidence has indicated that tumor-associated macrophages (TAMs) are associated with a favorable prognosis in patients with colon cancer, it is still unknown how TAMs exert a protective effect. This study examined whether TAMs are involved in hepatic metastasis of colon cancer.

Materials and methods: One hundred and sixty cases of pathologically-confirmed specimens were obtained from colon carcinoma patients with TNM stage IIIB and IV between January 1997 and July 2004 at the Cancer Center of Sun Yat-Sen University. The density of macrophages in the invasive front $\left(\mathrm{CD} 68 \mathrm{TF}_{\mathrm{Hotspot}}\right)$ was scored with an immunohistochemical assay. The relationship between the $\mathrm{CD} 68 \mathrm{TF}_{\text {Hotspot }}$ and the clinicopathologic parameters, the potential of hepatic metastasis, and the 5-year survival rate were analyzed.

Results: TAMs were associated with the incidence of hepatic metastasis and the 5-year survival rate in patients with colon cancers. Both univariate and multivariate analyses revealed that the CD68TF Hotspot was independently prognostic of survival. A higher 5-year survival rate among patients with stage IIIB after radical resection occurred in patients with a higher macrophage infiltration in the invasive front (81.0\%) than in those with a lower macrophage infiltration (48.6\%). Most importantly, the CD68TF Hotspot was associated with both the potential of hepatic metastasis and the interval between colon resection and the occurrence of hepatic metastasis.

Conclusion: This study showed evidence that TAMs infiltrated in the invasive front are associated with improvement in both hepatic metastasis and overall survival in colon cancer, implying that TAMs have protective potential in colon cancers and might serve as a novel therapeutic target.
\end{abstract}

\section{Background}

Colorectal cancer is the fourth leading cause of cancer deaths worldwide. Of patients with colorectal cancer, $35 \%-55 \%$ will develop hepatic metastases at some time during the course of their disease. Survival following hepatic resection of colorectal metastasis now approaches $35 \%-50 \%$. However, approximately $65 \%$ of patients will have a recurrence at 5 years. Identifying the markers for hepatic metastasis would be helpful for the early treatment of patients at high-risk of hepatic metastasis [1-5].

\footnotetext{
* Correspondence: zxs617@hotmail.com

'State Key Laboratory of Oncology in South China, Cancer Center, Sun YatSen University, 651 Dongfeng R E, 510060, Guangzhou, China
}

In addition to clonal selection and the predetermined metastatic potential of cancer cells, there is increasing evidence indicating that the microenvironment modifies the metastasis of cancer cells [6-9]. Cancer tissue is infiltrated with stromal cells including macrophages. Tumor-associated macrophages (TAMs) are not only abundant in epithelial cancers, but also involved in cancer progression [10-13]. Experimental data have indicated that ablation of macrophage function or inhibition of macrophage infiltration into experimental tumors inhibits tumor growth and metastases [14]. Additionally, gene array studies of diagnostic lymph node specimens in follicular lymphoma have shown that genes associated with a strong 'macrophage' signature are associated with a poorer prognosis, independent of clinical variables or of gene expression of the
C Biomed Central

(c) 2010 Zhou et al; licensee BioMed Central Ltd. This is an Open Access article distributed under the terms of the Creative Commons Attribution License (http://creativecommons.org/licenses/by/2.0), which permits unrestricted use, distribution, and reproduction in any medium, provided the original work is properly cited. 
tumor cells [15]. Therefore, TAMs might promote tumor progression by induction of chronic inflammation, matrix remodeling, tumor invasion, intravasation, angiogenesis, and seeding at distant sites [13]. In contrast, recruitment of TAMs also contributes to the development of an adaptive immune response against cancer. TAMs contribute to the balance between antigen availability and clearance through phagocytosis and subsequent degradation of senescent or apoptotic cells. The role of TAMs is essential for triggering, instructing, and terminating the adaptive immune response [16]. The clinical evidence regarding the relationship between TAMs and tumor progression is tumor type-dependent. The higher density of TAMs is associated with a poorer prognosis in leiomyosarcomas, melanomas, gliomas, and cancers of the breast, bladder, rectum, and endometrium, but the prognosis is favorable in nasopharyngeal, gastric, and ovarian cancers [17-28]. Additionally, in liver, lung, and prostate cancers, the role of TAMs on prognosis is controversial [29-35].

With respect to colorectal carcinomas, clinical data indicate that TAMs are associated with a favorable prognosis [36-39]. However, these studies have not indicated the sites at which TAMs show a protective effect. Because macrophages modify tumor invasion, intravasation, and angiogenesis, whether or not TAMs interfere with hepatic metastasis of colon cancer was determined in the current study.

\section{Materials and methods Materials}

One hundred and sixty cases of pathologically-confirmed specimens were obtained from colon carcinoma patients with TNM stage IIIB and IV between January 1997 and July 2004 at the Cancer Center of Sun YatSen University. Patients with stage IV colon carcinoma who were enrolled in this study had primary colon cancer with synchronous liver metastasis, irrespective of extra-hepatic involvement. Ninety-eight patients with stage IIIB colon carcinoma underwent radical surgery, while 62 patients with stage IV colon carcinoma underwent palliative colon resection with or without resection of hepatic lesions. None of the patients had undergone either chemotherapy or radiotherapy before the collection of the samples. The histopathologic characteristics of the colon carcinoma tissue specimens were confirmed by blinded review of the original pathology slides. The TNM classification system of the UICC (edition 6) was used for clinical staging, and the World Health Organization classification was used for pathologic grading. The study was conducted in accordance with the Helsinki Declaration and approved by the Ethics Committee of our institution. Patients were informed of the investigational nature of the study and provided their written informed consent.

\section{Follow-up of stage IIIB patients and post-operative treatment}

Clinical follow-up was only provided to stage IIIB patients, as patients with stage IV in this study were a group with high heterogeneity, including solitary or multiple liver metastases, and liver only or other sites involved with metastases; these variables affected the treatment protocols and eventually the response rate and prognosis. Ninety-eight patients with stage IIIB colon carcinoma were observed on an every-3-month basis during the $1^{\text {st }}$ year, once every 6 months in the $2^{\text {nd }}$ year, and by telephone or mail communication once every year thereafter for a total of 5 years. If recurrence or metastasis occurred, 5-FU-based chemotherapy was administered according to the NCCN guidelines [40]. Overall survival (OS) was defined as the time from surgery to death, or was censored at the last known alive data. Liver metastasis-free survival (LMFS) was defined as the time from surgery to liver metastasis.

\section{Immunohistochemistry}

The specimens were fixed in formaldehyde and embedded in paraffin. Only blocks containing the tumor front were evaluated. Tissue sections of $5-\mu \mathrm{m}$ thickness were cut, dried, deparaffinized, and rehydrated in a series of alcohols and xylene before antigen retrieval by pressure cooker treatment in citrate buffer ( $\mathrm{pH}$ 6.0) for 3 minutes. After that, we performed endogenous peroxidase blocking through hydrogen peroxide incubation. Mouse anti-human CD68 monoclonal antibody (mAb) (PG-M1; DakoCytomation, Glostrup, Denmark) at a 1:300 dilution was used. Immunostaining for CD68 was performed using EnVision + Dual Link Kit (Dako Cytomation) according to the manufacturer's instructions. The development was performed with a substrate-chromogen solution (3,3'-diaminobenzidine dihydrochloride [DAB]) for 3-5 minutes (brown reaction product). Sections were then counterstained with hematoxylin and mounted in non-aqueous mounting medium.

To analyze macrophage phenotypes, antibodies were stained as follows: 1$)$ IL-12 mAb (1:30, catalog number: sc-74147, mouse IgG1, Santa Cruz biotechnology, CA, USA), 2) human leukocyte antigen (HLA)-DR mAb (1:300, catalog number: ZM-0136, mouse IgG2b, Zhongshan Goldenbridge biotechnology, Beijing, China), 3) IL$10 \mathrm{Ab}$ (1:400, ab34843, rabbit polyclonal Ab, Abcam), 4) transforming growth factor beta1 (TGF- $\beta 1$ ) mAb (1:800, catalog number: sc-146, rabbit IgG, Santa Cruz biotechnology, CA, USA).

\section{CD68 evaluation}

Referring to Forssell's [36] scoring system, CD68 immunostaining along the tumor front was evaluated over the whole section (7-10 fields per section) and tumors 
containing small areas among which the infiltration of CD68-positive cells was considerably above the average level of CD68-positive cells was defined as CD68 hotspots $\left(\mathrm{CD} 6 \mathrm{TF}_{\text {Hotspot }}\right)$ [36]. All sections were evaluated far from necrosis areas and H.E. staining was reviewed in case of uncertainty. The CD68TF $\mathrm{TF}_{\text {Hotspot }}$ of the two highest view fields measured at $\times 200$ magnification was semi-quantitatively graded as no/weak (grade 1 ), moderate (grade 2), strong/robust (grade 3), and massive infiltration (grade 4). Tumors classified as 1 included completely negative specimens, as well as specimens containing some scattered CD68-positive cells along the tumor margin. Tumors were classified as 2 when CD68 staining was continuous along the tumor margin, but was not extended from the tumor front more than one cell layer on average. CD68 staining that, on average, extended 2-3 cell layers from the tumor margin over the whole section was classified as 3 , whereas to be classified as 4, CD68 staining extended several cell layers from the tumor margin in all fields. Each section was scored independently by two independent observers. Interobserver agreements for the CD68 $\mathrm{TF}_{\text {Hotspot }}$ were $81 \%$. Disagreements were re-evaluated until a consensus decision was made.

\section{Statistical analysis}

The relationship between the various clinicopathologic characteristics and the $\mathrm{CD} 68 \mathrm{TF}_{\mathrm{Hotspot}}$ parameters were compared and analyzed using $\chi^{2}$ tests, likelihood ratio, and linear-by-linear association, as appropriate. The cumulative survival time was computed using the Kaplan-Meier method and compared by the log-rank test. Univariate and multivariate analyses were based on the Cox proportional hazards regression model. A twotailed $\mathrm{P}<0.05$ was considered to be statistically significant. All statistical analyses were performed using SPSS 13.0 software for Windows (SPSS Inc., Chicago, IL, USA).

\section{Results}

\section{CD68 expression}

TAMs were stained brown in the cytoplasm. The majority of CD68-positive cells were located in the stroma, and in particular, along the invasive front. CD68-positive cells were mostly in apparent direct contact with or immediately adjacent to tumor cells lining the invasive front. Although most areas along the invasive front displayed a fairly homogeneous CD68+ infiltration pattern, there were also tumors containing small areas that showed CD68 infiltration considerably above the average grade $\left(\mathrm{CD} 68 \mathrm{TF}_{\text {Hotspot }}\right)$. The $\mathrm{CD} 68 \mathrm{TF}_{\text {Hotspot }}$ was semiquantitatively graded from 1-4 (Fig. 1).

To identify the phenotype of TAMs, a group of consecutive sections was used to stain with CD68, HLA-DR,
TGF- $\beta 1$, IL-10, and IL-12. TAMs were popularly stained with HLA-DR, IL-10, sporadically stained with TGF- $\beta 1$, negatively stained with IL-12, indicating that TAMs were activated without classic M1 or M2 phenotype (Fig. 2).

\section{Relationship between $\mathrm{CD} 68 \mathrm{TF}_{\mathrm{Hotspot}}$ and clinicopathologic characteristics}

We used the $\chi^{2}$ test to assess the relationship between the TAMs and clinicopathologic characteristics. The results showed that the $C D 68 \mathrm{TF}_{\text {Hotspot }}$ was inversely correlated with TNM stage, the presence of hepatic metastasis, and pathologic classification (Table 1). When hepatic metastasis status was cut into the following three patterns, the $\mathrm{CD} 6 \mathrm{TF}_{\text {Hotspot }}$ was also highly correlated with the status of hepatic metastasis: no hepatic metastasis (stage IIIB colon cancer without liver metastasis within 5 years of follow-up), metachronous hepatic metastasis (stage IIIB colon cancer with liver metastasis within 5 years of follow-up), and synchronous liver metastasis (stage IV colon cancer with liver metastasis before palliative surgery).

\section{Survival analyses}

By the end of the 5-year follow-up, 68 of patients with stage IIIB colon carcinoma were alive, thus the 5-year survival rate was $69.4 \%$. Based on univariate analysis, including all stage IIIB patients applicable to survival analyses $(\mathrm{n}=98)$, age, gender, tumor invasive depth, pathologic grade, and growth pattern showed no prognostic significance for OS and LMFS (Table 2). In contrast, the sites of primary tumors, pathologic classification, and hepatic metastasis were predictors for OS. The CD68 $\mathrm{TF}_{\text {Hotspot }}$ was highly correlated to OS ( $P$ $=0.001 ; \log$ rank test; data not shown), but not LMFS $(P=0.221 ; \log$ rank test; data not shown).

For further analysis, the grade data of the $\mathrm{CD} 68 \mathrm{TF}_{\mathrm{Hot}}$ spot were divided into 2 groups (grade 1 and 2 versus 3 and 4) according to Forssell's protocol [36]. Therefore, cases were regrouped into $\mathrm{CD} 6 \mathrm{TF}_{\mathrm{Hotspot}}$ high (3 and 4) versus $\mathrm{CD}_{68 \mathrm{TF}}$ Hotspot low (1 and 2) macrophage infiltration. Kaplan-Meier survival curves were then plotted to further investigate the association with OS. The logrank statistic was used to compare survival rates. There was a positive association between the $\mathrm{CD} 68 \mathrm{TF}_{\text {Hotspot }}$ group and both OS $(\mathrm{P}<0.001)$ and LMFS $(\mathrm{P}=0.037$; Fig. 3).

\section{Multivariate Cox proportional hazards analysis}

Whether or not the $\mathrm{CD} 6 \mathrm{TF}_{\mathrm{Hotspot}}$ group could serve as an independent predictor of OS and LMFS was analyzed. A multivariate Cox proportional hazards analysis was performed, including gender, age, sites of primary tumors, invasive depth, grade, pathologic classifications, 

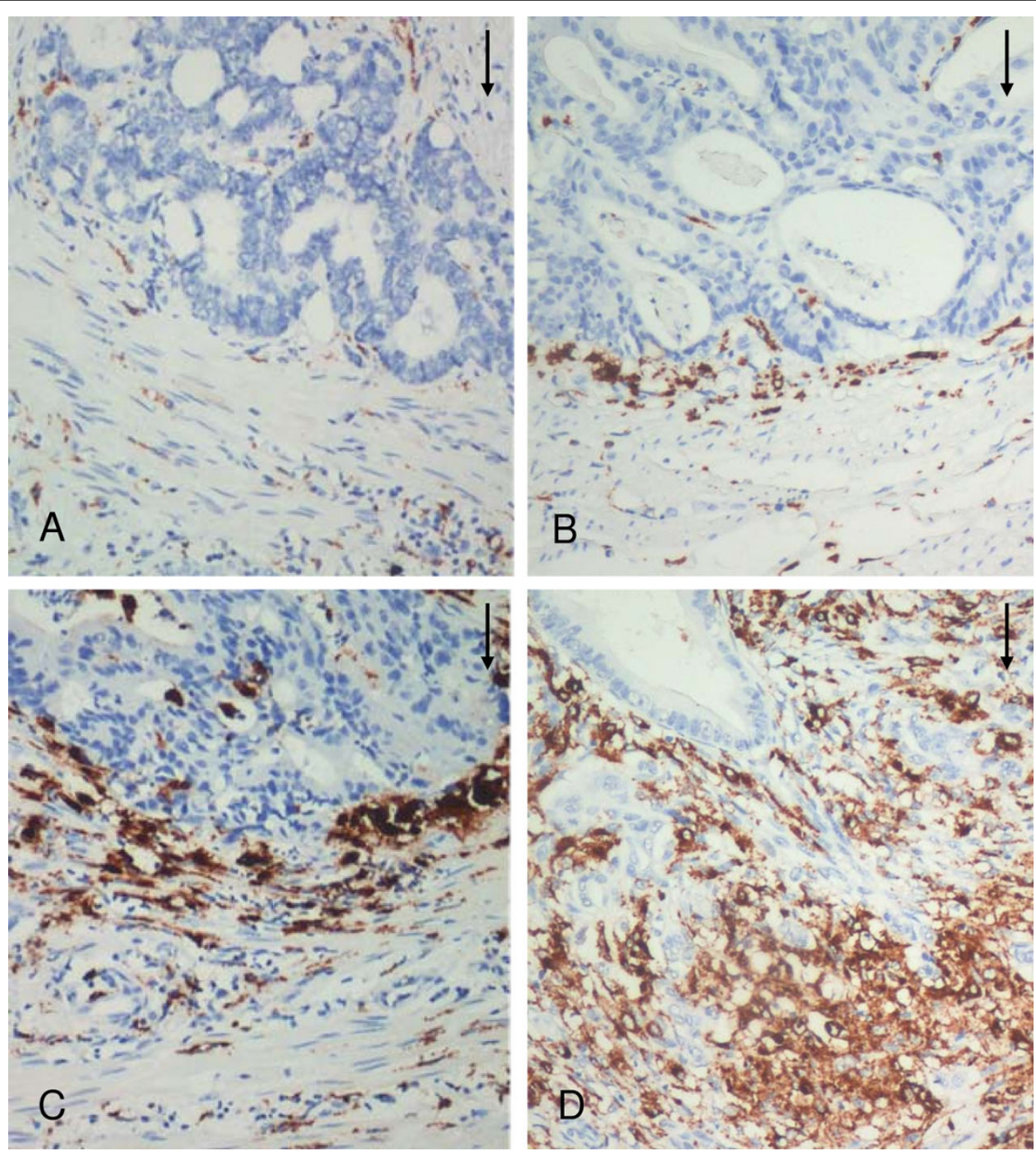

Figure 1 Representative pictures of $\mathrm{CD} 6 \mathrm{TF}_{\mathrm{Hotspot}}$ in colon cancer patients (200x magnification). Different grades of macrophage infiltration along the tumor front were examined with immunohistochemical assay: A, no/low, B, moderate, C, high, and D, massive. Arrows point at tumor front.

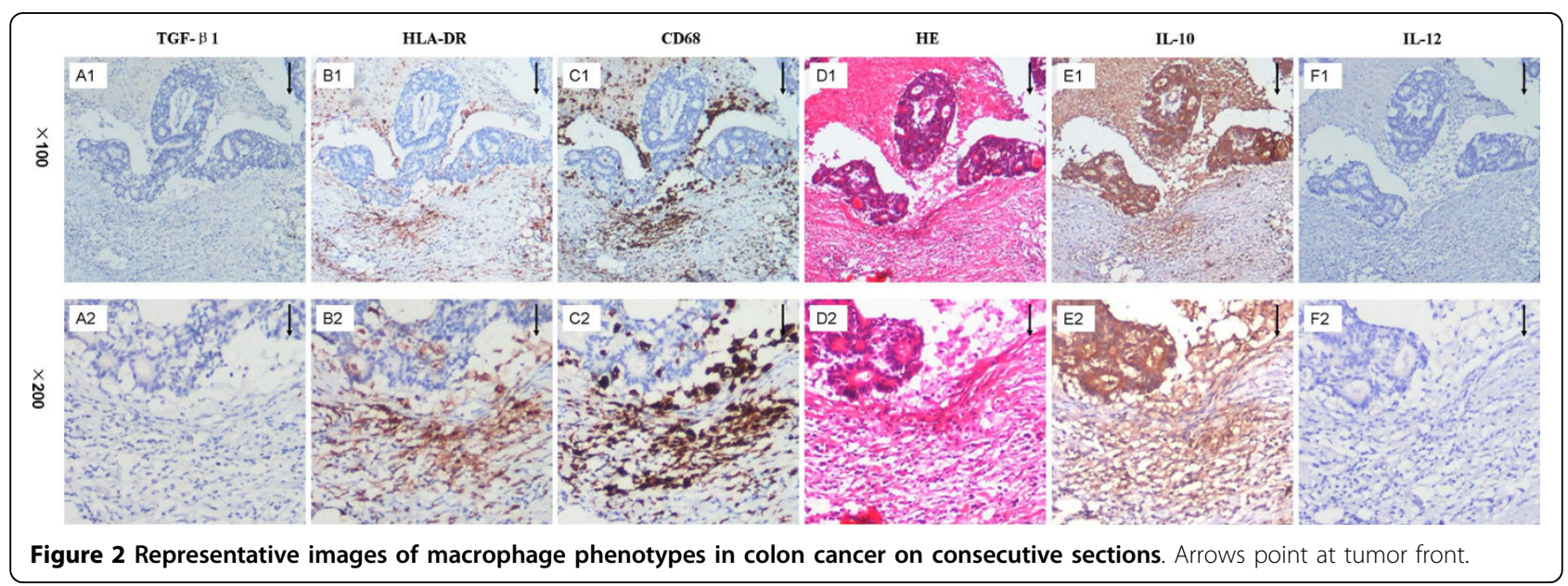


Table 1 Correlation between $\mathrm{CD} \mathrm{TTF}_{\text {Hotspot }}$ and clinicopathologic characteristics.

\begin{tabular}{|c|c|c|c|c|c|}
\hline \multirow[t]{3}{*}{ Variable } & \multicolumn{4}{|c|}{ CD68TF $_{\text {Hotspot }}$} & \multirow[t]{3}{*}{$P$ value } \\
\hline & $-/+$ & + & ++ & +++ & \\
\hline & 1 & 2 & 3 & 4 & \\
\hline \multicolumn{6}{|l|}{ Gender } \\
\hline Male & 23 & 21 & 37 & 13 & 0.939 \\
\hline Female & 15 & 13 & 27 & 11 & \\
\hline \multicolumn{6}{|l|}{ Age (years) } \\
\hline$<60$ & 22 & 17 & 26 & 15 & 0.195 \\
\hline$\geq 60$ & 16 & 17 & 38 & 9 & \\
\hline \multicolumn{6}{|l|}{ Sites of primary tumors } \\
\hline Left & 25 & 14 & 40 & 16 & 0.107 \\
\hline Right & 13 & 20 & 24 & 8 & \\
\hline \multicolumn{6}{|l|}{ TNM stages } \\
\hline IIIB & 17 & 18 & 46 & 17 & $0.025^{*}$ \\
\hline IV & 21 & 16 & 18 & 7 & \\
\hline \multicolumn{6}{|l|}{ Invasive depth } \\
\hline T3 & 31 & 30 & 53 & 17 & $0.422^{\mathrm{a}}$ \\
\hline T4 & 7 & 4 & 11 & 7 & \\
\hline \multicolumn{6}{|l|}{ Hepatic metastasis(1) } \\
\hline No & 13 & 14 & 42 & 16 & $0.004^{*}$ \\
\hline Yes & 25 & 20 & 22 & 8 & \\
\hline \multicolumn{6}{|l|}{ Hepatic metastasis(2) } \\
\hline No & 13 & 14 & 42 & 16 & $0.001^{* b}$ \\
\hline Metachronous & 4 & 4 & 4 & 1 & \\
\hline Synchronous & 21 & 16 & 18 & 7 & \\
\hline \multicolumn{6}{|l|}{ Grade } \\
\hline G1 & 1 & 1 & 1 & 0 & $0.124^{b}$ \\
\hline G2 & 23 & 21 & 48 & 21 & \\
\hline G3 & 14 & 11 & 14 & 2 & \\
\hline G4 & 0 & 1 & 1 & 1 & \\
\hline \multicolumn{6}{|l|}{ Pathologic classification } \\
\hline Papillary + tubular & 28 & 25 & 57 & 23 & $0.022^{* a}$ \\
\hline Mucoid + signet ring & 10 & 9 & 7 & 1 & \\
\hline \multicolumn{6}{|l|}{ Growth pattern } \\
\hline Pushing & 19 & 8 & 18 & 8 & 0.071 \\
\hline Infiltrating & 19 & 26 & 46 & 16 & \\
\hline
\end{tabular}

*: $p<0.05$. a: Likelihood ratio. b: Exact linear-by-linear association test.

liver metastasis, growth patterns, and $\mathrm{CD} 6 \mathrm{TF}_{\mathrm{Hotspot}}$ groups. In stage IIIB colon cancers, the high CD68 $\mathrm{TF}_{\text {Hotspot }}$ group had a significantly lower risk for OS (hazard ratio [HR], 0.433; 95\% confidence interval [CI], 0.194-0.966) and LMFS (HR, 0.265; 95\% CI, 0.0780.900) than did the low CD68 $\mathrm{TF}_{\text {Hotspot }}$ group. Liver metastasis (HR, 8.144; 95\% CI, 3.276-20.250) was an independent prognostic factor for OS. Additionally, patients with left colon cancer were prone to have a longer OS, whereas pathologic classification was not associated with OS (Table 3).

\section{Discussion}

By analyzing the relationship between the density of TAMs and the potential of hepatic metastasis and survival, this study showed that a higher density of macrophages in the invasive front of colon cancer was associated with a higher 5-year survival rate. Most importantly, the CD68TF $\mathrm{TF}_{\text {Hotspot }}$ was associated with both the incidence of hepatic metastasis and the interval between colon resection and the occurrence of hepatic metastasis.

In contrast to other solid tumors, such as breast cancer, most studies have shown that TAMs, especially IL12-positive TAMs, inhibit the progression of colon cancers [36-39,41-44]. For example, in Forssell's study [36] the higher macrophage infiltration along the tumor front correlated with improved survival in colon cancer compared to rectal cancer. In the current study, the Cox model indicated that the $\mathrm{CD} 68 \mathrm{TF}_{\mathrm{Hotspot}}$ was independently prognostic. A higher 5-year survival rate after radical resection occurred in patients with a higher macrophage infiltration in the invasive front (81.0\%) than in those with a lower macrophage infiltration (48.6\%), which is in agreement with the previous studies [36-39].

The mechanisms behind the antitumor effects of TAMs have not been fully elucidated and could potentially be ascribed to the M1 phenotype, which is in part controlled by the CD4+T cells and the death of cancer cells [45-47]. TAMs with the M1 phenotype are characterized by a high capacity to present antigen, high IL-12 and IL-23 production, and high production of toxic intermediates, such as nitric oxide and reactive oxygen intermediates. Thus, TAMs with the M1 phenotype are generally considered potent effector cells which kill tumor cells [48-51]. In fact, TAMs showed a spectrum from M1 to M2 phenotypes in murine colon adenocarcinoma tumors [52]. This study showed that TAMs expressed with HLA-DR and IL-10 rather than TGF- $\beta 1$ and IL-12, consistent with the previous observation [52]. Although an abundance of evidence relevant to the molecular mechanisms underlying the anti-tumor effect of macrophages has been documented, it is still unknown how TAMs exert a protective effect, except that one recent study indicated that TAMs reduce the development of peritoneal colorectal carcinoma metastases [36-39,41-44,53]. The current study analyzed the relationship between the infiltration of TAMs and hepatic metastasis. The results showed that a higher density of TAMs in the invasive front was associated with lower synchronous and metachronous hepatic metastases. Since hepatic metastasis of colon cancer is a key prognostic factor, this study might partly explain the 
Table 2 Univariate analyses of factors associated with OS and LMFS.

\begin{tabular}{|c|c|c|c|c|}
\hline \multirow[t]{2}{*}{ Variable } & \multicolumn{2}{|c|}{ OS $(n=98)$} & \multicolumn{2}{|c|}{ LMFS ( $n=98)$} \\
\hline & $\mathrm{HR},(95 \% \mathrm{Cl})$ & $P$ value & $\mathrm{HR},(95 \% \mathrm{Cl})$ & $P$ value \\
\hline Gender (female vs. male) & $1.157(0.562-2.381)$ & 0.693 & $0.416(0.114-1.510)$ & 0.182 \\
\hline Age $(<60$ y vs. $\geq 60$ y) & $0.732(0.352-1.519)$ & 0.402 & $0.704(0.230-2.153)$ & 0.538 \\
\hline Invasive depth (T4 vs. T3) & $1.023(0.392-2.674)$ & 0.962 & $0.902(0.200-4.068)$ & 0.893 \\
\hline Sites of primary tumors (right vs. left) & $2.271(1.093-4.717)$ & $0.028^{*}$ & $0.815(0.267-2.491)$ & 0.720 \\
\hline Grade (G3 vs. G2 vs. G1) & $1.519(0.715-3.224)$ & 0.277 & $1.036(0.324-3.311)$ & 0.953 \\
\hline Pathologic classification (mucoid + signet ring vs. papillary + tubular) & $2.415(1.129-5.168)$ & $0.023^{*}$ & $1.148(0.316-4.171)$ & 0.834 \\
\hline Growth pattern (infiltrating vs. pushing) & $0.817(0.389-1.718)$ & 0.595 & $2.709(0.600-12.223)$ & 0.195 \\
\hline CD68TF $_{\text {Hotspot }}$ (4 vs. 3 vs. 2 vs.1) & $0.568(0.393-0.822)$ & $0.003^{*}$ & $0.594(0.344-1.025)$ & 0.061 \\
\hline CD68TF $_{\text {Hotspot }}$ group (high vs. low) & $0.288(0.139-0.600)$ & $0.001^{*}$ & $0.324(0.106-0.991)$ & $0.048^{*}$ \\
\hline Hepatic metastasis (yes vs. no) & $5.852(2.737-12.511)$ & $0.000^{* *}$ & NA & NA \\
\hline
\end{tabular}

reason that macrophage infiltration improves the prognosis of patients with colon cancer.

The molecular mechanisms underlying hepatic metastasis of colon cancers is poorly understood. Traditional clinicopathologic indices for hepatic metastasis of colorectal cancer, which include the depth of invasion, the presence of venous invasion, and lymph node metastasis, have only limited prognostic value [54]. Although multiple markers, such as CD10, CD44, VEGF, TGF- $\alpha$, have been shown to be correlated with hepatic metastasis, the predictive efficacy of these markers is still unclear [55-60]. In the current study, a higher density of TAMs in the invasive front was associated with lower synchronous hepatic metastasis and lower metachronous hepatic metastasis, showing that the immune microenvironment of the primary tumor modifies the metastatic potential of colon cancer, and the function of TAMs is changeable in different tumor microenvironment [61].

Most immune cells, such as CD45RO+T cells, CD3 $+\mathrm{T}$ cells, NK cells, TAMs, and even Treg cells, have shown a protective effect when infiltrated into colon cancer tissue [62-67]. Additionally, an autoimmune response is associated with the efficacy of biochemotherapy (GOLFIG regimen) for colon cancer $[68,69]$. The current study has given additional evidence that macrophage infiltration is involved in the inhibition of hepatic metastasis. These data indicate that colon cancer is an immunogenic tumor. Therefore, more

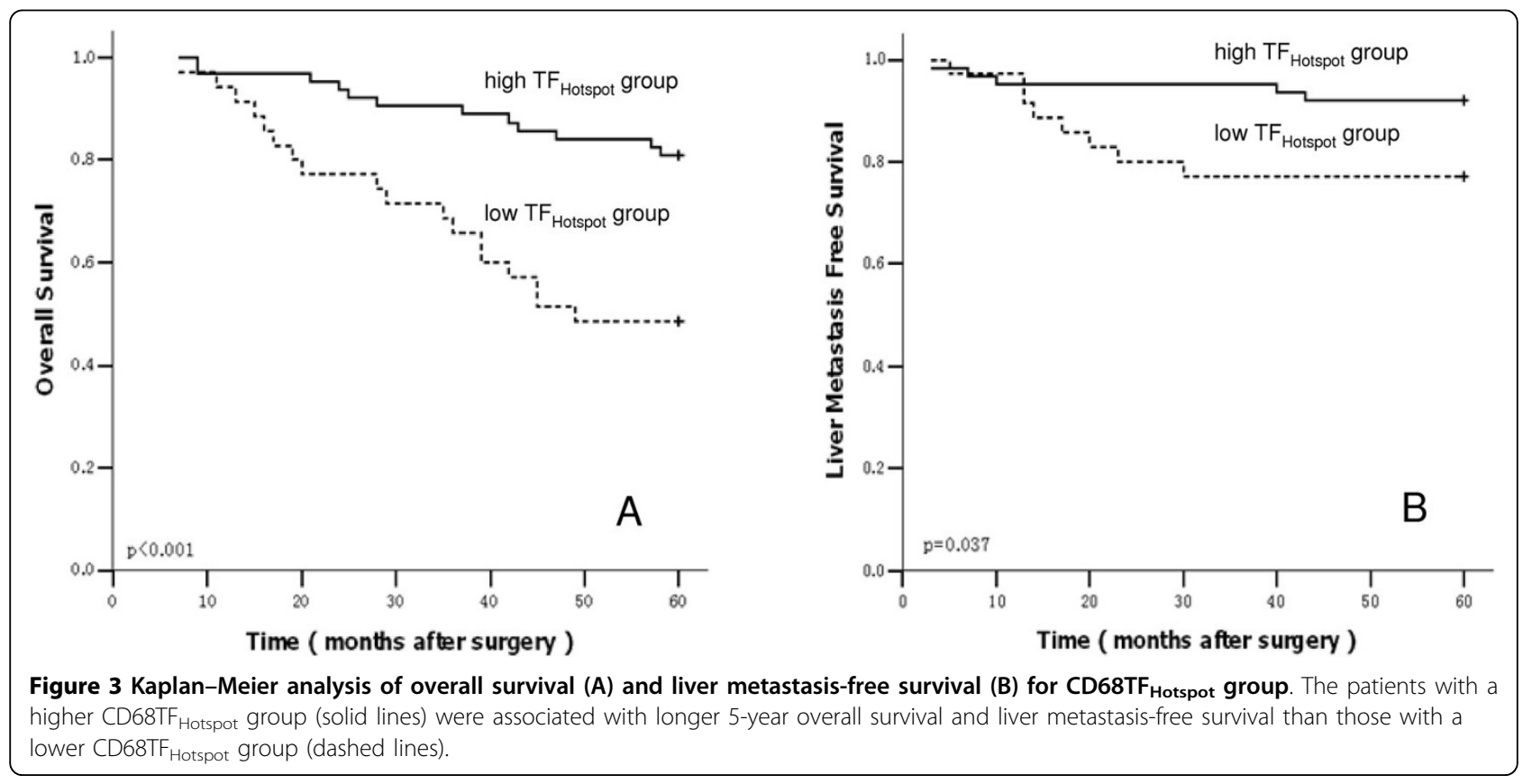


Table 3 Multivariate analyses of factors associated with OS and LMFS

\begin{tabular}{lllll}
\hline Variable & \multicolumn{1}{c}{ OS $(\mathbf{n}=\mathbf{9 8})$} & \multicolumn{2}{c}{ LMFS $(\mathbf{n}=\mathbf{9 8})$} \\
\cline { 2 - 5 } & HR, (95\% Cl) & P value & HR, (95\% Cl) & P value \\
\hline Gender (female vs. male) & $1.954(0.841-4.538)$ & 0.119 & $0.333(0.083-1.335)$ & 0.121 \\
\hline Age $(<60$ y vs. $\geq 60$ y) & $0.504(0.227-1.116)$ & 0.091 & $0.881(0.267-2.906)$ & 0.835 \\
\hline Invasive depth (T4 vs. T3) & $1.941(0.693-5.436)$ & 0.207 & $0.846(0.171-4.190)$ & 0.838 \\
\hline Site of primary tumors (right vs. left) & $2.184(0.981-4.859)$ & 0.056 & $1.009(0.298-3.414)$ & 0.989 \\
\hline Grade (G3 vs. G2 vs. G1) & $1.224(0.457-3.281)$ & 0.688 & $1.616(0.345-7.575)$ & 0.543 \\
\hline Pathologic Classification (mucoid + signet ring vs. papillary + tubular) & $2.364(0.787-7.100)$ & 0.125 & $0.537(0.071-4.061)$ & 0.547 \\
\hline Growth patterns (infiltrating vs. pushing) & $0.700(0.295-1.662)$ & 0.419 & $2.650(0.551-12.746)$ & 0.224 \\
\hline CD68TF ${ }_{\text {Hotspot } \text { group (high vs. low) }}$ & $0.433(0.194-0.966)$ & $0.041^{*}$ & $0.265(0.078-0.900)$ & $0.033^{*}$ \\
\hline Liver metastasis (yes vs. no) & $8.144(3.276-20.250)$ & $0.000^{* *}$ & NA & NA \\
\hline
\end{tabular}

Multivariate analysis, Cox proportional hazard regression model. Abbreviations: HR, hazard ratio; $\mathrm{Cl}$, confidence interval; NA, not assessment. *: $\mathrm{p}<0.05$; **: $\mathrm{p}<$ 0.001 .

attention should be paid to exploiting the immune response in an effort to improve conventional therapy for colon cancer [70].

Additionally, our study main aim is to find if there any relationship between macrophages and liver metastasis in colon cancer which was cut into the following three patterns: no hepatic metastasis, metachronous and synchronous liver metastasis. We decided to choose single stage IIIB colon cancer which is the biggest group in our center colon resource database to avoid the influence of different stages factor on relationship between macrophages and liver metastasis. Although this constitution minimized confounding factors, it cannot completely represent ordinary setup, so our results, and as such, should be viewed with some caution.

\section{Conclusion}

This study demonstrated that TAMs infiltrated in the invasive front are associated with improvement in both hepatic metastasis and OS in colon cancer, implying that TAMs have protective potential in colon cancers and might serve as a novel therapeutic target.

\section{Acknowledgements}

This study was supported by research grants from the National Nature Science Foundation (30972882) and the Nature Science Foundation of Guangdong Province, China (9151008901000149).

\section{Author details}

${ }^{1}$ State Key Laboratory of Oncology in South China, Cancer Center, Sun YatSen University, 651 Dongfeng R E, 510060, Guangzhou, China. ²Biotherapy Center, Cancer Center, Sun Yat-Sen University, 651 Dongfeng R E, 510060, Guangzhou, China. ${ }^{3}$ Department of Colorectal Oncology, Cancer Center, Sun Yat-Sen University, 651 Dongfeng R E, 510060, Guangzhou, China.

${ }^{4}$ Department of Pathology, Cancer Center, Sun Yat-Sen University, 651 Dongfeng R E, 510060, Guangzhou, China.

\section{Authors' contributions}

WXJ, DY, ZQM, PZZ, and WDS carried out the case collection; $Z Q, X Q$, and $\mathrm{HJH}$ carried out the immunohistochemical staining; and PRQ and ZX analyzed the results. ZXS and ZYX conceived the study, participated in the design, and coordinated and helped draft the manuscript. All authors read and approved the final manuscript.

\section{Competing interests}

The authors declare that they have no competing interests.

Received: 3 November 2009

Accepted: 8 February 2010 Published: 8 February 2010

\section{References}

1. Mayo SC, Pawlik TM: Current management of colorectal hepatic metastasis. Expert Rev Gastroenterol Hepatol 2009, 3(2):131-144.

2. Duffy MJ, van Dalen A, Haglund C, Hansson L, Holinski-Feder E, Klapdor R, Lamerz R, Peltomaki P, Sturgeon C, Topolcan O: Tumour markers in colorectal cancer: European Group on Tumour Markers (EGTM) guidelines for clinical use. Eur J Cancer 2007, 43(9):1348-1360.

3. Shah A, Alberts S, Adam R: Accomplishments in 2007 in the management of curable metastatic colorectal cancer. Gastrointest Cancer Res 2008, 2(3 Suppl):S13-18.

4. Shrivastav A, Varma S, Saxena A, DeCoteau J, Sharma RK: Nmyristoyltransferase: a potential novel diagnostic marker for colon cancer. J Transl Med 2007, 5:58.

5. Lind $G E$, Ahlquist $T$, Kolberg M, Berg M, Eknaes M, Alonso MA, Kallioniemi A, Meling Gl, Skotheim Rl, Rognum TO, Thiis-Evensen E, Lothe RA: Hypermethylated MAL gene - a silent marker of early colon tumorigenesis. J Trans/ Med 2008, 6:13.

6. Eccles SA, Welch DR: Metastasis: recent discoveries and novel treatment strategies. Lancet 2007, 369(9574):1742-1757.

7. Li CY, Li BX, Liang Y, Peng RQ, Ding Y, Xu DZ, Zhang X, Pan ZZ, Wan DS, Zeng $Y X$, Zhu XF, Zhang XS: Higher percentage of CD133+ cells is associated with poor prognosis in colon carcinoma patients with stage IIIB. J Transl Med 2009, 7:56.

8. Gao YF, Peng RQ, Li J, Ding Y, Zhang X, Wu XJ, Pan ZZ, Wan DS, Zeng YX, Zhang XS: The paradoxical patterns of expression of indoleamine 2,3dioxygenase in colon cancer. J Transl Med 2009, 7:71.

9. Kopfstein L, Christofori G: Metastasis: cell-autonomous mechanisms versus contributions by the tumor microenvironment. Cell Mol Life Sci 2006, 63(4):449-468.

10. Hallam S, Escorcio-Correia M, Soper R, Schultheiss A, Hagemann T: Activated macrophages in the tumour microenvironment-dancing to the tune of TLR and NF-kappaB. J Pathol 2009, 219(2):143-152.

11. Hagemann T, Lawrence T, McNeish I, Charles KA, Kulbe H, Thompson RG, Robinson SC, Balkwill FR: "Re-educating" tumor-associated macrophages by targeting NF-kappaB. J Exp Med 2008, 205(6):1261-1268.

12. Hagemann T, Biswas SK, Lawrence T, Sica A, Lewis CE: Regulation of macrophage function in tumors: the multifaceted role of NF-kappaB. Blood 2009, 113(14):3139-3146. 
13. Condeelis J, Pollard JW: Macrophages: obligate partners for tumor cell migration, invasion, and metastasis. Cell 2006, 124(2):263-266.

14. Lin EY, Nguyen AV, Russell RG, Pollard JW: Colony-stimulating factor 1 promotes progression of mammary tumors to malignancy. $J$ Exp Med 2001, 193(6):727-740.

15. Dave SS, Wright G, Tan B, Rosenwald A, Gascoyne RD, Chan WC, Fisher RI, Braziel RM, Rimsza LM, Grogan TM, Miller TP, LeBlanc M, Greiner TC, Weisenburger DD, Lynch JC, Vose J, Armitage JO, Smeland EB, Kvaloy S, Holte H, Delabie J, Connors JM, Lansdorp PM, Ouyang Q, Lister TA, Davies AJ, Norton AJ, Muller-Hermelink HK, Ott G, Campo E, Montserrat E, Wilson WH, Jaffe ES, Simon R, Yang L, Powell J, Zhao H, Goldschmidt N, Chiorazzi M, Staudt LM: Prediction of survival in follicular lymphoma based on molecular features of tumor-infiltrating immune cells. N Engl J Med 2004, 351(21):2159-2169.

16. Siveen KS, Kuttan G: Role of macrophages in tumour progression. Immunol Lett 2009, 123(2):97-102.

17. Nishie A, Ono M, Shono T, Fukushi J, Otsubo M, Onoue $H$, Ito $Y$, Inamura $T$, Ikezaki K, Fukui M, Iwaki T, Kuwano M: Macrophage infiltration and heme oxygenase-1 expression correlate with angiogenesis in human gliomas. Clin Cancer Res 1999, 5(5):1107-1113.

18. Leek RD, Lewis CE, Whitehouse R, Greenall M, Clarke J, Harris AL: Association of macrophage infiltration with angiogenesis and prognosis in invasive breast carcinoma. Cancer Res 1996, 56(20):4625-4629.

19. Pollard JW: Macrophages define the invasive microenvironment in breast cancer. J Leukoc Biol 2008, 84(3):623-630.

20. Shabo I, Stål O, Olsson H, Doré S, Svanvik J: Breast cancer expression of CD163, a macrophage scavenger receptor, is related to early distant recurrence and reduced patient survival. Int J Cancer 2008, 123(4):780-786.

21. Hanada T, Nakagawa M, Emoto A, Nomura T, Nasu N, Nomura Y: Prognostic value of tumor-associated macrophage count in human bladder cancer. Int J Urol 2000, 7(7):263-269.

22. Shabo I, Olsson H, Sun XF, Svanvik J: Expression of the macrophage antigen CD163 in rectal cancer cells is associated with early local recurrence and reduced survival time. Int J Cancer 2009, 125(8):1826-1831.

23. Salvesen HB, Akslen LA: Significance of tumour-associated macrophages, vascular endothelial growth factor and thrombospondin-1 expression for tumour angiogenesis and prognosis in endometrial carcinomas. Int $J$ Cancer 1999, 84(5):538-543.

24. Lee $\mathrm{CH}$, Espinosa I, Vrijaldenhoven $\mathrm{S}$, Subramanian $\mathrm{S}$, Montgomery KD, Zhu S, Marinelli RJ, Peterse JL, Poulin N, Nielsen TO, West RB, Gilks CB, Rijn van de M: Prognostic significance of macrophage infiltration in leiomyosarcomas. Clin Cancer Res 2008, 14(5):1423-1430.

25. Jensen TO, Schmidt H, Møller HJ, Høyer M, Maniecki MB, Sjoegren $P$, Christensen IJ, Steiniche T: Macrophage markers in serum and tumor have prognostic impact in American Joint Committee on Cancer stage I/ II melanoma. J Clin Oncol 2009, 27(20):3330-3337.

26. Ohno S, Inagawa H, Dhar DK, Fujii T, Ueda S, Tachibana M, Suzuki N, Inoue $\mathrm{M}$, Soma $\mathrm{G}$, Nagasue $\mathrm{N}$ : The degree of macrophage infiltration into the cancer cell nest is a significant predictor of survival in gastric cancer patients. Anticancer Res 2003, 23(6D):5015-5022.

27. Tanaka Y, Kobayashi H, Suzuki M, Kanayama N, Suzuki M, Terao T: Upregulation of bikunin in tumor-infiltrating macrophages as a factor of favorable prognosis in ovarian cancer. Gynecol Oncol 2004, 94(3):725-734.

28. Peng J, Ding T, Zheng LM, Shao JY: Influence of tumor-associated macrophages on progression and prognosis of nasopharyngeal carcinoma. Ai Zheng 2006, 25(11):1340-1345, [Article in Chinese].

29. Ding T, Xu J, Wang F, Shi M, Zhang Y, Li SP, Zheng L: High tumorinfiltrating macrophage density predicts poor prognosis in patients with primary hepatocellular carcinoma after resection. Hum Pathol 2009, 40(3):381-389.

30. Li YW, Qiu SJ, Fan J, Gao Q, Zhou J, Xiao YS, Xu Y, Wang XY, Sun J, Huang XW: Tumor-infiltrating macrophages can predict favorable prognosis in hepatocellular carcinoma after resection. $J$ Cancer Res Clin Oncol 2009, 135(3):439-449.

31. Kawai O, Ishii G, Kubota K, Murata Y, Naito Y, Mizuno T, Aokage K, Saijo N, Nishiwaki Y, Gemma A, Kudoh S, Ochiai A: Predominant infiltration of macrophages and CD8(+) T Cells in cancer nests is a significant predictor of survival in stage IV nonsmall cell lung cancer. Cancer 2008, 113(6):1387-1395.
32. Welsh TJ, Green RH, Richardson D, Waller DA, O'Byrne KJ, Bradding P: Macrophage and mast-cell invasion of tumor cell islets confers a marked survival advantage in non-small-cell lung cancer. J Clin Oncol 2005, 23(35):8959-8967.

33. Kataki A, Scheid P, Piet M, Marie B, Martinet N, Martinet $Y$, Vignaud JM: Tumor infiltrating lymphocytes and macrophages have a potential dual role in lung cancer by supporting both host-defense and tumor progression. J Lab Clin Med 2002, 140(5):320-328.

34. Richardsen E, Uglehus RD, Due J, Busch C, Busund LT: The prognostic impact of M-CSF, CSF-1 receptor, CD68 and CD3 in prostatic carcinoma. Histopathology 2008, 53(1):30-38.

35. Lissbrant IF, Stattin P, Wikstrom P, Damber JE, Egevad L, Bergh A: Tumor associated macrophages in human prostate cancer: relation to clinicopathological variables and survival. Int J Oncol 2000, 17(3):445-451.

36. Forssell J, Oberg A, Henriksson ML, Stenling R, Jung A, Palmqvist R: High macrophage infiltration along the tumor front correlates with improved survival in colon cancer. Clin Cancer Res 2007, 13(5):1472-1479.

37. Nagorsen $D$, Voigt $S$, Berg E, Stein $H$, Thiel E, Loddenkemper C: Tumorinfiltrating macrophages and dendritic cells in human colorectal cancer: relation to local regulatory $T$ cells, systemic T-cell response against tumor-associated antigens and survival. J Trans/ Med 2007, 5:62.

38. Funada Y, Noguchi T, Kikuchi R, Takeno S, Uchida Y, Gabbert HE: Prognostic significance of CD8+ T cell and macrophage peritumoral infiltration in colorectal cancer. Oncol Rep 2003, 10(2):309-313.

39. Sugita J, Ohtani H, Mizoi T, Saito K, Shiiba K, Sasaki I, Matsuno S, Yagita H, Miyazawa M, Nagura H: Close association between Fas ligand (FasL; CD95L)- positive tumor-associated macrophages and apoptotic cancer cells along invasive margin of colorectal carcinoma: a proposal on tumor-host interactions. Jpn J Cancer Res 2002, 93(3):320-328.

40. National Comprehensive Cancer Network. http://www.nccn.org/ professionals/physician_gls/PDF/colon.pdf.

41. Kuniyasu H, Sasaki T, Sasahira T, Ohmori H, Takahashi T: Depletion of tumor-infiltrating macrophages is associated with amphoterin expression in colon cancer. Pathobiology 2004, 71(3):129-136.

42. Bacman D, Merkel S, Croner R, Papadopoulos T, Brueckl W, Dimmler A: TGFbeta receptor 2 downregulation in tumour-associated stroma worsens prognosis and high-grade tumours show more tumour-associated macrophages and lower TGF-beta1 expression in colon carcinoma: a retrospective study. BMC Cancer 2007, 7:156.

43. Inoue $Y$, Nakayama $Y$, Minagawa N, Katsuki T, Nagashima N, Matsumoto $K$, Shibao K, Tsurudome Y, Hirata K, Nagata N, Itoh H: Relationship between interleukin-12-expressing cells and antigen-presenting cells in patients with colorectal cancer. Anticancer Res 2005, 25(5):3541-3546.

44. Tan SY, Fan Y, Luo HS, Shen ZX, Guo Y, Zhao LJ: Prognostic significance of cell infiltrations of immunosurveillance in colorectal cancer. World J Gastroenterol 2005, 11(8):1210-1214.

45. Umemura $N$, Saio M, Suwa $T$, Kitoh $Y$, Bai J, Nonaka K, Ouyang GF, Okada M, Balazs M, Adany R, Shibata T, Takami T: Tumor-infiltrating myeloid-derived suppressor cells are pleiotropic-inflamed monocytes/ macrophages that bear M1- and M2-type characteristics. J Leukoc Biol 2008, 83(5):1136-1144.

46. Weigert A, Tzieply N, von Knethen A, Johann AM, Schmidt H, Geisslinger G, Brüne B: Tumor cell apoptosis polarizes macrophages role of sphingosine- 1-phosphate. Mol Biol Cell 2007, 18(10):3810-3819.

47. DeNardo DG, Barreto JB, Andreu P, Vasquez L, Tawfik D, Kolhatkar N, Coussens LM: CD4(+) T cells regulate pulmonary metastasis of mammary carcinomas by enhancing protumor properties of macrophages. Cancer Cell 2009, 16(2):91-102.

48. Mantovani A, Sica A, Allavena P, Garlanda C, Locati M: Tumor-associated macrophages and the related myeloid-derived suppressor cells as a paradigm of the diversity of macrophage activation. Hum Immunol 2009, 70(5):325-330.

49. Sica A, Schioppa T, Mantovani A, Allavena P: Tumour-associated macrophages are a distinct M2 polarised population promoting tumour progression: potential targets of anti-cancer therapy. Eur J Cancer 2006, 42(6):717-727.

50. Gordon S, Taylor PR: Monocyte and macrophage heterogeneity. Nat Rev Immunol 2005, 5(12):953-964.

51. Pollard JW: Trophic macrophages in development and disease. Nat Rev Immunol 2009, 9(4):259-270. 
52. Umemura N, Saio M, Suwa T, Kitoh Y, Bai J, Nonaka K, Ouyang GF, Okada M, Balazs M, Adany R, Shibata T, Takami T: Tumor-infiltrating myeloid- derived suppressor cells are pleiotropic-inflamed monocytes/ macrophages that bear M1- and M2-type characteristics. J Leukoc Biol 2008, 83(5):1136-1144.

53. Bij van der GJ, Bögels M, Oosterling SJ, Kroon J, Schuckmann DT, de Vries HE, Meijer S, Beelen $\mathrm{RH}$, van Egmond M: Tumor infiltrating macrophages reduce development of peritoneal colorectal carcinoma metastases. Cancer Lett 2008.

54. Bird NC, Mangnall D, Majeed AW: Biology of colorectal liver metastases: A review. J Surg Oncol 2006, 94(1):68-80.

55. Fang YJ, Lu ZH, Wang GQ, Pan ZZ, Zhou ZW, Yun JP, Zhang MF, Wan DS: Elevated expressions of MMP7, TROP2, and survivin are associated with survival, disease recurrence, and liver metastasis of colon cancer. Int J Colorectal Dis 2009, 24(8):875-884.

56. Barozzi C, Ravaioli M, D’Errico A, Grazi GL, Poggioli G, Cavrini G, Mazziotti A, Grigioni WF: Relevance of biologic markers in colorectal carcinoma: a comparative study of a broad panel. Cancer 2002, 94(3):647-657.

57. Kato H, Semba S, Miskad UA, Seo Y, Kasuga M, Yokozaki H: High expression of PRL-3 promotes cancer cell motility and liver metastasis in human colorectal cancer: a predictive molecular marker of metachronous liver and lung metastases. Clin Cancer Res 2004, 10(21):7318-7128.

58. Ohji Y, Yao T, Eguchi T, Yamada T, Hirahashi M, lida M, Tsuneyoshi M: Evaluation of risk of liver metastasis in colorectal adenocarcinoma based on the combination of risk factors including CD10 expression: multivariate analysis of clinicopathological and immunohistochemical factors. Oncol Rep 2007, 17(3):525-530.

59. Tanami H, Tsuda H, Okabe S, Iwai T, Sugihara K, Imoto I, Inazawa J: Involvement of cyclin D3 in liver metastasis of colorectal cancer, revealed by genome-wide copy-number analysis. Lab Invest 2005, 85(9):1118-1129.

60. Hu H, Sun L, Guo C, Liu Q, Zhou Z, Peng L, Pan J, Yu L, Lou J, Yang Z, Zhao $P$, Ran $Y$ : Tumor cell-microenvironment interaction models coupled with clinical validation reveal CCL2 and SNCG as two predictors of colorectal cancer hepatic metastasis. Clin Cancer Res 2009, 15(17):5485-5493.

61. Nonaka K, Saio M, Suwa T, Frey AB, Umemura N, Imai H, Ouyang GF, Osada S, Balazs M, Adany R, Kawaguchi Y, Yoshida K, Takami T: Skewing the Th cell phenotype toward Th1 alters the maturation of tumorinfiltrating mononuclear phagocytes. J Leukoc Biol 2008, 84(3):679-688,

62. Laghi L, Bianchi P, Miranda E, Balladore E, Pacetti V, Grizzi F, Allavena P, Torri V, Repici A, Santoro A, Mantovani A, Roncalli M, Malesci A: CD3+ cells at the invasive margin of deeply invading (pT3-T4) colorectal cancer and risk of post-surgical metastasis: a longitudinal study. Lancet Oncol 2009, 10(9):877-884.

63. Pagès $F$, Berger $A$, Camus $M$, Sanchez-Cabo $F$, Costes $A$, Molidor $R$, Mlecnik B, Kirilovsky A, Nilsson M, Damotte D, Meatchi T, Bruneval P Cugnenc PH, Trajanoski Z, Fridman WH, Galon J: Effector memory T cells, early metastasis, and survival in colorectal cancer. N Engl J Med 2005, 353(25):2654-2666

64. Salama P, Phillips M, Grieu F, Morris M, Zeps N, Joseph D, Platell C, lacopetta B: Tumor-infiltrating FOXP3+ T regulatory cells show strong prognostic significance in colorectal cancer. J Clin Oncol 2009, 27(2):186-192.

65. Sandel MH, Speetjens FM, Menon AG, Albertsson PA, Basse PH, Hokland M, Nagelkerke JF, Tollenaar RA, Velde van de CJ, Kuppen PJ: Natural killer cells infiltrating colorectal cancer and MHC class I expression. Mol Immunol 2005, 42(4):54154-6.

66. Ohtani H: Focus on TILs: prognostic significance of tumor infiltrating lymphocytes in human colorectal cancer. Cancer Immun 2007, 7:4

67. Gout S, Huot J: Role of cancer microenvironment in metastasis: focus on colon cancer. Cancer Microenviron 2008, 1(1):69-83.

68. Correale P, Cusi MG, Tsang KY, Del Vecchio MT, Marsili S, Placa ML, Intrivici C, Aquino A, Micheli L, Nencini C, Ferrari F, Giorgi G, Bonmassar E, Francini G: Chemo-immunotherapy of metastatic colorectal carcinoma with gemcitabine plus FOLFOX 4 followed by subcutaneous granulocyte macrophage colony- stimulating factor and interleukin-2 induces strong immunologic and antitumor activity in metastatic colon cancer patients. J Clin Oncol 2005, 23(35):8950-8958

69. Correale $\mathrm{P}$, Tagliaferri P, Fioravanti A, Del Vecchio MT, Remondo C, Montagnani F, Rotundo MS, Ginanneschi C, Martellucci I, Francini E,
Cusi MG, Tassone P, Francini G: Immunity feedback and clinical outcome in colon cancer patients undergoing chemoimmunotherapy with gemcitabine + FOLFOX followed by subcutaneous granulocyte macrophage colony- stimulating factor and aldesleukin (GOLFIG-1 Trial). Clin Cancer Res 2008, 14(13):4192-499.

70. Stout RD, Watkins SK, Suttles J: Functional plasticity of macrophages: in situ reprogramming of tumor-associated macrophages. J Leukoc Biol 2009, 86(5):1105-1109.

doi:10.1186/1479-5876-8-13

Cite this article as: Zhou et al:: The density of macrophages in the invasive front is inversely correlated to liver metastasis in colon cancer. Journal of Translational Medicine 2010 8:13.

\section{Submit your next manuscript to BioMed Central and take full advantage of:}

- Convenient online submission

- Thorough peer review

- No space constraints or color figure charges

- Immediate publication on acceptance

- Inclusion in PubMed, CAS, Scopus and Google Scholar

- Research which is freely available for redistribution 